\title{
Business Practices and Customers Satisfaction among Motorcycle Dealers in General Santos City
}

\author{
Mylene M. Turco, Roel D. Juevesa, Arvin T. Galigao \\ College of Business Education, Ramon Magsaysay Memorial Colleges, General Santos City, Philippines \\ Email: myleneturco.cbe@gmail.com
}

How to cite this paper: Turco, M. M., Juevesa, R. D., \& Galigao, A. T. (2021). Business Practices and Customers Satisfaction among Motorcycle Dealers in General Santos City. Open Journal of Business and Management, 9, 460-487.

https://doi.org/10.4236/ojbm.2021.91025

Received: January 7, 2021

Accepted: January 26, 2021

Published: January 29, 2021

Copyright ( 2021 by author(s) and Scientific Research Publishing Inc. This work is licensed under the Creative Commons Attribution International License (CC BY 4.0).

http://creativecommons.org/licenses/by/4.0/

\begin{abstract}
This study aimed to determine the significant relationship between business practices and customers satisfaction among motorcycle dealers in General Santos City, Philippines. The descriptive survey and correlational design were used to employ quantitative data. The data were gathered through the survey questionnaire from eight (8) managers and forty (40) customers of the identified motorcycle dealers who were selected through purposive sampling. The data gathered were analyzed through weighted mean and Pearson (r) Coefficient Correlation. The findings of the study generally revealed that there is a significant relationship between business practices and customers satisfaction. Therefore, the null hypothesis that there is no significant relationship between business practices and customers satisfaction is rejected. Given the overall results, the study recommends sustaining the business practices in order to maintain the current level of customers satisfaction.
\end{abstract}

\section{Keywords}

Business Practices, Customer Satisfaction, Motorcycle Dealers, General Santos City, Philippines

\section{Introduction}

In today's traffic conditions where commuters are complaining of the daily traffic predicament in the main streets of the city, many passengers and vehicle owners are opting to buy and use motorcycle as a mode of transportation to avoid traffic congestion (Hanlon, 2012; Reinsalu, 2018). Motorcycles are inexpensive form of motorized transport in any part of the world. In the country, it is used as a personal service and public transport like tricycle and "habal-habal" 
especially, in the sub-urban areas all over the Philippines (Guillen \& Ishida, 2004). The motorcycle giant producers like Honda, Kawasaki, Suzuki, and Yamaha are producing economically, environmentally and price-friendly models intended for the developing countries as their market like the Philippines.

The Motorcycle Development Program Participants Association (MDPPA) released its 2018 sales report on February 2019 achieving 21\% annual sales growth with a total of $1,580,926$ units sold for the year. The association expects the upward trend in motorcycle sales to continue as it forecasted a $20 \%$ increase in sales in 2019 (Roces, 2018). In fact, Magkilat (2014) stated that in terms of production volume, the Philippines ranked the fourth largest in ASEAN surpassing Malaysia. The Philippines also ranked 8th world's motorcycle hub overtaking Japan. Aside from a strong domestic market, motorcycle manufacturing has also a wide industry linkage (Carmudi, 2018; Tamehiro, 2019; F+L Daily, 2017).

In General Santos City, the number of motorcycle dealers is growing (eportal.gensantos.gov.ph, 2020) with the goal to compete and take the place of the market leaders in the industry. In fact, the motorcycle industry's primary focus is selling products to class $\mathrm{C}$ and D markets through installments. Motorcycle dealers' activities depend on suppliers' support and program, competition, market condition, demographic condition and other factors. Since, dealers are obtaining stocks directly from head office in Manila, shipment of stocks varies on how fast dealers are placing orders and how timely dealers are paying the suppliers based on the specified terms and conditions. As part of the covenant, dealers are required to obey the imposed policies of suppliers in terms of shipment procedure, pricing scheme, promotion, preventive maintenance, warranty claims, and provision of trainings and seminars. Due to dealers' dependency on suppliers ordering and shipment policies, warranty claim procedures, and other dealers' benefits offered by the latter, problems occur when dealers deviate in conforming to suppliers' standard procedures. Delayed shipment of ordered stocks and parts, cutting off of subsidies, disapproval of warranty claims, reduction of dealers' rebates and the like arises when dealers deviate in conforming to suppliers' policies and procedures. To achieve the highest market share and to maximize profit, dealers are competing with one another in terms of providing services to target customers.

The most common business practices of local motorcycle dealers include monitoring of competitors' activities to outwit one another, sending of personnel to suppliers sponsored off the job trainings and seminars, and complying with the suppliers' requirements to avail the latter's lowest price offerings and financial grants or subsidy. To gain the trust and loyalty of customers, dealers offer lucrative sales and marketing promotions to customers. These promotions include designing an attractive financing scheme through offering lower down payment, lower financing rates; and availability of freebies; the provision of free and comfortable amenities to customers; and the best after sales services through 
scheduling of free preventive maintenance check-up. These activities brought competition to dealers prompting them to exert extensive efforts not only to satisfy the needs and want of the customers, but to augment sales and service revenues and to increase collection efficiency.

As motorcycle dealers are thriving into the industry, complaints are also received. As stated by Maddox (2016), Laurel (2017), the common problems are generally revolving on: delayed service appointments and repairs, defective motorcycle, defective battery, non-release of mortgage, problem on deposited unit being sold, issues on payment scheme, defective unit, and credit restructuring. Moreover, other problems like delayed registration and non-issuance of plates (Sino Cruz, 2019).

Thus, streamlining of better business practices for motorcycle dealers are called for in serving the customers (Adusei \& Tweneboah-Koduah, 2019). Therefore, conducting a study on the business practices of motorcycle dealers and the level of customers satisfaction is necessary.

\section{Theoretical and Conceptual Framework}

This study was based on the concepts of Evans \& Lindsay (2013) who stated that "a company that invested in quality management efforts experience outstanding returns and improvements in performance. Various research studies showed that quality-focused companies achieved better employee participation and relations, improved product and service quality, higher productivity, greater customer satisfaction, increased market share, and improved profitability".

The concepts of Kotler \& Armstrong (2014) in which this study was anchored, stated that the secret to building long term customer relationships is to create superior customer value and satisfaction. Satisfied customers are more likely to become loyal customers and give the company a higher share of profit. Customers satisfaction depends on the product's perceived performance relative to buyers' expectations.

In addition, if performance matches expectations the customers are satisfied. If performance exceeds expectations, the customers will become highly satisfied or delighted. If the performance fall shorts of expectations the customers will be dissatisfied. Delighted customers will not only make frequent purchases but also become willing marketing partners and serve as the "customer evangelist" who spread the word about their best experiences to the company.

The two concepts presented the relationship between the business practices and customers satisfaction of motorcycle dealers in General Santos City.

Figure 1 presented illustrated the schematic diagram of the conceptual framework of the study. The inputs on business practices of motorcycle dealers include the: management, sales and marketing, and finance. On the other hand, the customer satisfactions are: sales and marketing, financing and after sales service. 


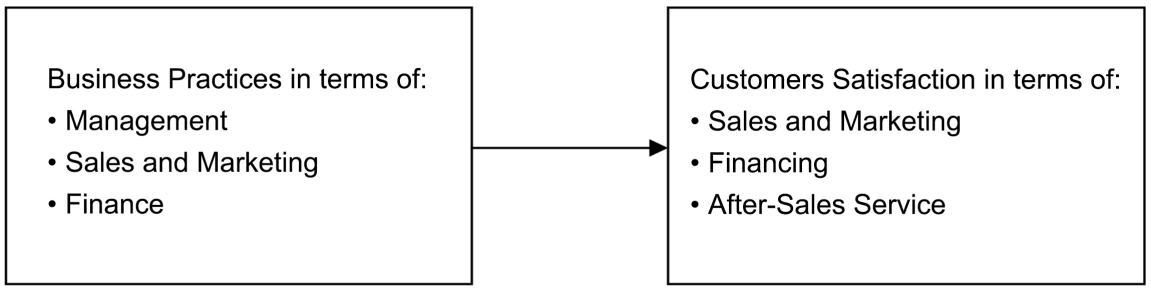

Figure 1. Conceptual framework of the study.

\section{Statement of the Problem and Research Hypothesis}

This study determined the business practices and the level of customers satisfaction provided by motorcycle dealers in General Santos City.

Specifically, the study answered the following questions:

1) What are the business practices of the motorcycle dealers in General Santos City as to:

a) Management;

b) Sales and Marketing; and

c) Finance?

2) What is the level of customer's service satisfaction on the customer service activities of the motorcycle dealers in General Santos City in terms of:

a) Sales and Marketing;

b) Financing; and

c) After Sales Services?

3) Is there a significant relationship between the motorcycle dealers' business practices and level of customers service satisfaction?

Based on the given statement of the problems, the research hypothesis of the study is "HO1: There is no significant relationship between the business practices of motorcycle dealers and the level of customers satisfaction among motorcycle dealers in General Santos City".

\section{Research Methodology}

\subsection{Research Design}

The study used a descriptive survey and correlational research design.

Calmorin \& Calmorin (2012) stated that a descriptive method of research is a study that focuses on present condition and appraises carefully the worthiness of the current study, the obtained facts about existing conditions or detaches significant relationship between current phenomena. It described and interpreted prevailing condition or relationship that exist or do not exist, the practices that prevail or not, beliefs or points of view or attitude that are held, processes that are going on or otherwise, effects that were being felt, or trends that were developed.

Moreover, this method was used to determine the correlation of the business practices of motorcycle dealers and the customers level of satisfaction. Besides, this method is the most appropriate method in presenting the relationships of the two variables. 


\subsection{Locale of the Study}

The study was conducted in General Santos City where the eight (8) motorcycle dealers were located. This highly urbanized city is composed of twenty-six (26) barangays with a total population of six hundred fifty-eight thousand three hundred two $(658,302)$ (populationstat.com, n.d.) in which a certain percentage of the adult population already owns motorcycles as mode of transportation. Part of its adult population serves as the target market of the registered motorcycle dealers.

The City is home to different motorcycle dealers because of its booming economic activity. The presence of exclusive Honda motorcycle dealers like Belinda; Desmark; Honda Mega Motors; and Powercycle; and other multi brand dealers like Cyclehaus; Motortrade; Transcycle; and Viajero was an indication of a high marketability of motorcycle units.

\subsection{Respondents of the Study}

The respondents of the study were the eight (8) managers and forty (40) customers of the identified motorcycle dealers in General Santos City.

The identified dealers were selected based on the business category which are the exclusive and the multi brand, and are considered as the major players in the motorcycle industry. The components considered are the form of business organization, the years of existence in the industry which is from five (5) years and above, organizational structure, and the popularity of the brands catered which are also considered as the fastest moving motorcycles considering its volume of sales in the industry.

On the respondents, they determine using the purposive sampling technique. Bloor \& Wood (2006) explained that purposive sampling speaks of the purposive or judgment sample as a deliberate sampling technique where the researcher selects a particular group or groups based on certain criteria of purposes or variables. It is a sample selected by a researcher which in his judgment is a representative sample. Calmorin \& Calmorin (2012) explained that an individual will be selected as part of the sample due to good evidence that he is a representative of the total population.

Thus, the eight (8) managers were selected because of their authority, job position, job functions and their knowledge of the business practices. While, the forty (40) customers of the identified motorcycle dealers or five (5) customers from each dealer were chosen purposively to answer the survey questionnaire because they are those individuals who can directly evaluate the services provided by dealers.

However, the results of customers answer on the SQ were corroborated through in-depth interview to the management. It is to be noted that during the interview, the identity of the interviewees was protected. Thus, no real name has been mentioned. 


\subsection{Research Instruments}

A self-made survey questionnaire (SQ) was utilized in obtaining data needed to present the business practices and the level of customers' satisfaction. Accordingly, Questionnaire is a list of questions which the respondents are requested to respond to secure responses or facts to certain questions, information about conditions or practices of which the respondents are presumed to have knowledge (Garcia \& Juevesa, 2020).

In this study, the first part was related to the profile of respondents. The second part deals with business practices concentrating in the areas of management, sales and marketing, and financing. The respondents were asked to score each aspect using the Likert-like scale to complete the set of questions. The score five (5) was the highest indicating that the respondents are highly practicing the services. The score 1 was the lowest score indicating that the respondents do not practice the customer service. The third part was related to the level of customers' satisfaction in terms of management, sales and marketing, financing and after-sales service. Again, the respondents were asked to score each aspect using the Likert-like scale to complete the set of questions. The score five (5) is the highest score implying that the respondents were very satisfied with the services. The score 1 is the lowest score indicating that the respondents were very dissatisfied with the customers' services.

This is to be noted that the SQ was validated by five (5) identified experts of which three (3) of them from the academe and another two (2) from the industry. Moreover, the instrument according to its content was certified and tested in terms of reliability. This will determine if the objectives of the study will be achieved and appropriate data will be gathered for the study.

\subsection{Statistical Treatment}

The data gathered from each respondent were tallied, tabulated and subjected to the following statistical treatment.

Weighted Mean, it was used to measure the central tendencies of the data gathered in variable of business practices and customers satisfaction.

Pearson ( $r$ ) Coefficient Correlation, it was used to measure the strength and linear association between two variables. This was used to determine the mean relationship of the business practices and customers satisfaction.

\section{Results and Discussion}

\subsection{Business Practices of Motorcycle Dealers}

Three tables are presented to discuss the business practices of motorcycle dealers in General Santos City-Table 1 presents dealers' management practices, Table 2 presents dealers' sales and marketing practices, and Table 3 presents dealer's financing practices. 
Table 1. Business practices as to management.

\begin{tabular}{|c|c|c|}
\hline Indicators & Mean & Interpretation \\
\hline $\begin{array}{l}\text { 1) Dealer forecasts monthly sales prior to ordering from } \\
\text { suppliers. }\end{array}$ & 4.75 & Very Highly Practiced \\
\hline $\begin{array}{l}\text { 2) Dealer conducts monthly inventory to track availability } \\
\text { of stocks. }\end{array}$ & 5.00 & Very Highly Practiced \\
\hline $\begin{array}{l}\text { 3) Dealer follows schedule of hauling and delivery of } \\
\text { products. }\end{array}$ & 4.50 & Very Highly Practiced \\
\hline $\begin{array}{l}\text { 4) Dealer has warehouse where products are placed and } \\
\text { store. }\end{array}$ & 5.00 & Very Highly Practiced \\
\hline $\begin{array}{l}\text { 5) Dealer has a delivery vehicle used in hauling and } \\
\text { delivering motorcycle unit or parts. }\end{array}$ & 4.25 & Highly Practiced \\
\hline $\begin{array}{l}\text { 6) Dealer's service income increased due to repairs and } \\
\text { maintenance activities. }\end{array}$ & 4.00 & Highly Practiced \\
\hline $\begin{array}{l}\text { 7) Services of sales personnel and mechanic contribute a } \\
\text { lot in the profitability of the dealer. }\end{array}$ & 4.63 & Very Highly Practiced \\
\hline $\begin{array}{l}\text { 8) The overall income of the dealer depends on the } \\
\text { management and best service provided to customers. }\end{array}$ & 4.88 & Very Highly Practiced \\
\hline Overall & 4.63 & Very Highly Practiced \\
\hline
\end{tabular}

Table 2. Business practices as to sales and marketing.

\begin{tabular}{|c|c|c|}
\hline Indicators & Mean & Interpretation \\
\hline 1) Sales are obtained through walk in customers. & 3.75 & Highly Practiced \\
\hline 2) Sales are obtained through sales agents or intermediaries. & 2.38 & Fairly Practiced \\
\hline $\begin{array}{l}\text { 3) Dealer promotes the product using advertising media } \\
\text { like TV, radio and newspaper. }\end{array}$ & 3.00 & Moderately Practiced \\
\hline 4) Dealer conducts monthly marketing activities. & 3.88 & Highly Practiced \\
\hline $\begin{array}{l}\text { 5) Dealer offers promotional freebies and other promotional } \\
\text { items provided by suppliers. }\end{array}$ & 4.25 & Highly Practiced \\
\hline $\begin{array}{l}\text { 6) Dealer tracks and compares previous month's sales of } \\
\text { motorcycle units and service revenue against the current } \\
\text { month. }\end{array}$ & 4.38 & Highly Practiced \\
\hline $\begin{array}{l}\text { 7) Dealer offers commission to mechanics, sales agents } \\
\text { and display center. }\end{array}$ & 3.13 & Moderately Practiced \\
\hline $\begin{array}{l}\text { 8) The motorcycle prices and service rates are priced lower } \\
\text { than the competitors. }\end{array}$ & 3.88 & Highly Practiced \\
\hline Overall & 3.58 & Highly Practiced \\
\hline
\end{tabular}


Table 3. Business practices as to financing.

\begin{tabular}{|c|c|c|}
\hline Indicators & Mean & Interpretation \\
\hline $\begin{array}{l}\text { 1) Dealer offers easy installment plan for motorcycle } \\
\text { products. }\end{array}$ & 4.63 & Very Highly Practiced \\
\hline 2) Dealer offers low down payment. & 4.13 & Highly Practiced \\
\hline $\begin{array}{l}\text { 3) Dealer offers low interest rate on installment than } \\
\text { the competitors. }\end{array}$ & 3.88 & Highly Practiced \\
\hline $\begin{array}{l}\text { 4) Dealer offers rebates, full payment discount, } \\
\text { restructuring, and change of financing term. }\end{array}$ & 4.63 & Very Highly Practiced \\
\hline $\begin{array}{l}\text { 5) Dealer has clear credit and collection policies } \\
\text { imposed to the applicants. }\end{array}$ & 4.75 & Very Highly Practiced \\
\hline $\begin{array}{l}\text { 6) Credit and collection personnel strictly follow the } \\
\text { company policies in granting credit and collecting payments. }\end{array}$ & 4.38 & Highly Practiced \\
\hline $\begin{array}{l}\text { 7) Dealer gives incentives to credit appraisers and } \\
\text { collectors. }\end{array}$ & 3.75 & Highly Practiced \\
\hline $\begin{array}{l}\text { 8) Dealer sends credit and collection personnel to trainings } \\
\text { and seminars. }\end{array}$ & 4.75 & Very Highly Practiced \\
\hline Overall & 4.36 & Highly Practiced \\
\hline
\end{tabular}

As shown in Table 1, the dealers' business practices in terms of management are detailed in eight (8) indicators.

Among the eight (8) indicators detailed in the table above, six (6) were rated very highly practiced in which two indicators had a perfect rating of 5.00, while the two other indicators were rated highly practiced. The result showed that the dealers do not miss to conduct monthly inventory to track availability of stocks to avoid loss of sales and income and all of them have warehouses where their products are placed and stored. This implies that dealers' practices in terms of managing a motorcycle business are constantly monitored the in and out of stocks and the stored products for sale in the warehouses for safety and control purposes.

According to Heizer \& Render (2014) record accuracy is a prerequisite to inventory management, production scheduling, and sales. Accuracy can be maintained by implementing a periodic or perpetual system. Periodic systems require regular checks of inventory to determine quantity on hand. Small retailers and facilities use this kind of inventory system. Perpetual inventory tracks both the receipts and subtractions from inventory on a continuing basis. Regardless of the inventory system, record accuracy requires good incoming and outgoing record keeping as well as good security. According to Bowersox et al. (2014) storage has always been an important aspect of economic development of an organization. The economic benefits of warehousing occur when overall logistics costs are reduced. Warehouses stored inventory in the logistic channel, serving to coordi- 
nate product and consumer demand. Strategic warehousing serves to satisfy both the consumers and the motorcycle dealers and benefit reaped are the economic and service fulfillment.

As shown in the table, the indicator with the relatively least mean (4.00) stated that the dealers' service income increased due to repairs and maintenance activities. The estimated monthly increase in service income ranges from ten (10) to twenty (20) percent. The findings of the study revealed that as practiced dealers hire experienced mechanics that had undergone proper technical training prior to employment. This was confirmed by Manager $\mathrm{C}$ when she stated that So far, our mechanics are well trained and we do not accept mechanics without proper training. In addition, the common practices of dealers are requesting a subsidized technical training from suppliers to equip shop personnel with technical know-how specifically on newly manufactured product and providing service orientations to enhance mechanic's competency and to keep abreast with the new models produced by suppliers for them to provide the best service in the repairs and maintenance of motorcycles.

Although the mechanics were technically trained prior to engaging to respective works, dealers' lack the initiative to assess other training needs of mechanics like customers complaints handling or customer relationship management because they are also dealing with customers directly from those customers availing shop services that may affect the provision of customers service in general. This was affirmed by Manager $\mathrm{F}$ when he mentioned that "Nowadays, we can say that we have a good training with our mechanics. However, we have new models for example the FI models from different suppliers that need an additional training for the mechanics".

Shown in Table 2 are the business practices of motorcycle dealers in terms of sales and marketing. Of the eight indicators that reflect this business practice, none was rated very highly practiced, five indicators were rated highly practiced, two were rated moderately practiced, and one was rated the lowest rating of fairly practiced. With the highest mean of 4.38 , the dealers track and compare previous month's sales of motorcycle units and service revenue against the current month. The result disclosed that one of the strengths of dealers in managing sales is by tracking monthly sales and revenue trends. However, this may not be enough since the reasons for erratic sales were not analyzed in depth. In addition, dealers rely mainly on walk-in customers. According to Young \& Pagoso (2012) sales personnel performs one of the many tasks for the organization while providing the services at the same time preparing sales report and sales analysis aside from approaching prospect buyers and presenting the products. The result was affirmed in the study of Walker Jr. \& Mullins (2014) which indicated that sales analysis involves breaking down aggregate sales data into such categories as product, end users, customers, sales territories and order size. The objective of such analysis is to find areas of strengths and weaknesses.

Also shown in Table 2, the dealers moderately practiced promoting their 
products using advertising media like TV, radio and newspaper, and they also moderately practiced offering commission to mechanics, sales agents and display center. The result of the study showed that there was a stiff competition in the motorcycle industry. Confronted with stiff competition, dealers' falters in conducting information drive through advertising like television, radio and print advertisements. Although dealers want to implement those sales promotion activities yet, dealers were dependent on the financial subsidies of the suppliers in implementing the said advertising medium because using tri-media as advertising tool is costly on the part of dealers. Even though, dealers were implementing monthly information dissemination by using mainly print media in the form of flyers or leaflets. This marketing tool used has a limited reach in promoting the motorcycle products and was not a strong marketing tool that would entice buyers to patronize dealers' products. Because of their reliance on suppliers' subsidies, dealers do not really have a comprehensive marketing campaign which is consistent. According to Balasan (2014) sales promotion is an important marketing effort of any organization in making the public aware of the existence of a product or service. Sales promotion also includes marketing activities other than personal selling, advertising and publicly designed to enhance consumer purchasing and dealer effectiveness (Kurtz, 2013). It was confirmed by Futrell (2014) when he expounded that personal selling, advertising, publicity and sales promotion are the main ingredients of an organizations promotional effort. The outcome of the study was further proved in the study of Liu (2001) entitled, "An Assessment of Banking Operation Strategies of Private Banking Institutions in the Philippines", the findings discussed how a variety of media exposures was used through broadcast and print media which were considered by the research as the most effective means of promoting the bank's products and services.

This was affirmed by Manager D when he said that "Of course, marketing, marketing activities like radio ads, TV rolling, so that people could see what is new in Motortrade, but it is expensive which is not applicable as of now". In addition, it was corroborated by Manager F when he confirmed that "To us, in order to speed up the outflow-inflow of customers especially in sales, we need the support of suppliers in every model that they sell, for example if it is okay with them to give freebies and giveaways for every model, and marketing activity for every department, suppliers to have their own marketing activity per model is so much better".

As shown in Table 2, the indicator with the least mean (2.38) indicates that sales are obtained through sales agent or intermediaries. The findings of the study revealed that most of the dealers are relying on walk in customers and majority of them do not employ sales agents or intermediaries. Motorcycle dealership competition is high, yet dealers do not use various marketing tools like hiring of sales agents and middlemen to promote motorcycle products and services. The findings demonstrated the need of dealers to implement different 
sales strategies using middlemen to generate more sales that would definitely augment volume of sales. Considering the stiff competition in the motorcycle industry, middlemen could contribute in generating more sales that would definitely result in an increase in profit and growth in service revenues.

Interviews also revealed that dealers were relying mainly on sales strategies. For instance, the use of intermediaries is a good way in promoting the products and services. Employing one, would greatly help the promotion of the dealers' products and services especially, in the far-flung areas where there is a need to penetrate the market. This was affirmed by Manager $\mathrm{H}$ who emphasized that "Other dealers have their own sales agents here in Desmark, we have walk-in customers only". The result was contradicted by Manager B when he said that "In sales, you have to be ahead with others in marketing, so, your salespeople should have activities in the field let's say leafleting and mobile caravan so that we will be known".

Shown in Table 3 above are the business practices of dealers in terms of financing. Of the eight indicators, four were rated very highly practiced and four were rated highly practiced.

Results showed that almost all dealers send credit and collection personnel to trainings and seminars. The findings also revealed that the training program of the credit and collection department of motorcycle dealers were in place as evidenced by the rating of 4.75. Although credit and collection personnel were sent to trainings yet, customers were not very satisfied with the services of dealers especially, in the aspect of issues pertaining to financing schemes. For example, these personnel cannot fully explain why overdue customers cannot avail rebates and those customers who do not pay on time. Interview result from Manager $\mathrm{C}$ who said that "We stick on a policy of on or before due date rebates, no rebates given after the due date". The result of the study was contradicted in the study of Ravindra \& Sorsa (2015) entitled, “A Study on Customer Satisfaction towards BAJAJ Motorbikes in Hawassa, Ethiopia, Africa", which presented that respondents have accepted the price offerings of the motorcycle dealers.

The result indicated that in spite of the trainings of credit and collection personnel, the latter still needs improvement in order to become more skillful in conducting credit investigation and to be more adept in collecting customers because the collection efficiency is not one hundred percent (100\%). These personnel also lack the skills in convincing customers to pay on time as evidenced by the existence of deposited units almost every month. In addition, the outcome also presented some weakness in credit and collection system like the presence of unscrupulous and incompetent credit appraisers and collectors who accept payments from the customers who cannot pass the criteria for credit that resulted to low efficiency and overdue accounts. Manager $\mathrm{H}$ said that "There is no process because he was paid to approve". He added that "There is, that was the most difficult customer that he had released, those customers that we cannot repossess). It was confirmed by Manager E when he stated that "For now ma'am, 
the problem is that those units that we had pulled out because of the mistakes of the company is that our CI are accepting bribes from the customers. Instead, to undergo proper credit investigation customers that are not qualified were approved because they were paid. Usually, nowadays, dealers had encountered problems with credit investigators and that is the result of many repossessed". According to Medina (2012) training has been an important human activity and in the business world, it is regarded as an attempt to improve the employees' ability to perform job so that the goals of the organization can be achieved. Through training, the gap between the employee's skills and the expectation to perform well would be addressed.

Also, with a rating of 4.75 , the dealers claim that they have clear credit and collection policies imposed to the applicants. The result of the study revealed that credit and collection personnel observed strictly the credit and collection policies imposed by the owners. As part of the practices, dealers strictly execute the credit and collection policies to the applicants applying to avail motorcycle through easy installment. This means that the credit and collection policies are in place and are effectively carried out. In spite of the clear credit and collection policy imposed yet, customers were demanding to avail rebates. The result of the study revealed that customers did not fully understand the policies simply, because the policies were not clearly explained to the customers prior to the release of the motorcycle unit. Misunderstanding leads to confusion of customers and results to non-conformity of customers to follow the credit and collection policies specifically, paying in a timely manner.

This may also indicate that there was a problem with the attitude of the customers because those who are availing the products and services were customers coming from the class $\mathrm{C}$ and class $\mathrm{D}$ which means that those were customers who cannot afford to buy motorcycles in cash and units purchased through installment were used for livelihood like "habal-habal", "trisikad", tricycle, delivery and some are for personal service. As explained by Briones (2005) credit and collections policies are designed or set at various levels, tactical policies at the middle management level and operational policies for the rank and file. Different credit organizations have different credit and collection policies which are often compiled in a manual. According to Manager B, when he stated that "It is not like that, it is not about the rebates that they are asking for, but it is the discount in the penalty charges or combination of the full waving of penalty".

With the least mean rating of 3.75, the dealers are highly practicing giving incentives to credit appraisers and collectors. The result of the study presented that collectors were rewarded through individual incentives. However, there is a need to review and redesign the incentive plan for credit appraisers and collectors to become more productive and motivated to perform tasks because credit appraisers and collectors are one of the key personnel of dealers who contribute much in gaining profit. If credit and collection personnel were highly motivated, collection efficiency would increase and quality sales would be produced which 
would result in gaining high profit. In addition, the rewards offered by dealers were not effective to collectors because, credit and collection personnel were easily bribed by disapproved customers who want to avail the product through installment. The result indicated that credit and collection personnel were not sincere and were dishonest in doing the job. In fact, credit appraisers were accepting bribe money from customers in lieu of credit approval. According to Castleberry \& Tanner Jr. (2014) bribery is a payment made to buyers to influence their purchase decisions and sales agents personally benefit from bribes, but these payments have negative effect to the sales agent's organization because product quality was not considered in buying decision. Interview result was affirmed by Manager E when he expressed that "For now ma'am, the problem is the number of units that we have pulled out, because of the mistakes of the CI that accept payment. Yes, they were bribed".

Briones (2005) explained that collectors' incentive program that is in place in many credit organizations is a prudent management practice to recognize the efforts of credit appraisers and collectors. An incentive program is designed to make employees do what the management wants them to do and it motivates them to achieve the financial goals of the organization. It was also confirmed in the concept of Griffin \& Moorehead (2014) which stated that incentive systems are plans in which employees can earn additional compensation in return for certain types of performance. It was further affirmed in the theory of Dubrin (2013) which stated that a natural way to motivate workers at any level is to offer them financial incentives for good performance. Using financial incentives to motivate people fits principles of positive reinforcement and punishment. A useful principle for using financial incentives to motivate workers at all levels is to investigate which incentives are most appealing to groups and individuals.

The summary of results on dealers' business practices is shown. The results indicate that the dealers' management practices, as reflected in the eight indicators previously presented, are very highly practiced in motorcycle dealership in General Santos City. It is also shown that both areas of sales and marketing and financing, as both reflected by their respective eight indicators previously presented, were highly practiced by the dealers. With these results in Table 4 it indicates that the dealers put high regard on the three areas of business practices.

Table 4. Summary of business practices.

\begin{tabular}{ccc}
\hline Area & Mean & Interpretation \\
\hline Management & 4.63 & Very Highly Practiced \\
Sales and Marketing & 3.58 & Highly Practiced \\
Financing & 4.36 & Highly Practiced \\
Overall & 4.18 & Highly Practiced \\
\hline
\end{tabular}


Overall, the eight motorcycle dealers in General Santos City highly practiced the aforementioned business activities which were regarded as contributing factors to their success in motorcycle dealerships. According to Amojelar (2012) Department of Trade and Industry was looking at the auto and motorcycle dealers in terms of their sales practices which have been complained. The complaints involved not selling in cash, instead the buyers were compelled to buy in installment basis and the latter put off selling in cash forcing the buyers to buy through financing. Delivery through cash purchases was delayed compared to purchases in installment. The trade secretary said that it was an unfair trade practice. In General Santos City, the unethical practice of hoarding motorcycle units was not applied by dealers, which means that the dealers have a good distribution management system because of the availability of stocks at all times.

The summary of results implies that dealers are mindful of the business practices. The goals of dealers are to sustain competitive advantages like providing enough stocks for the customers to choose from a variety of motorcycle models, offering low down payment, low interest rate, low monthly amortization and the best service they could provide to gain profit and maintain its edge in the market. Business practices of motorcycle dealers in terms of management, sales and marketing, and financing requires strategic administration and application of effective management approaches and decisions applicable in different settings.

\subsection{Customer's Level of Satisfaction on the Customer Service Activities of the Motorcycle Dealers in General Santos City}

Three tables are presented to discuss the level of customer's satisfaction on the service activities of motorcycle dealers in General Santos City-Table 5 presents level of customers satisfaction to sales and marketing activities of dealers, Table 6 presents level of customers satisfaction to financing activities of dealers, and Table 7 presents level of customers satisfaction to after sales services of dealers. Each table contains indicators of each of these three areas of activities.

As shown in Table 5 below, the indicators pertaining to customers satisfaction on sales and marketing activities of motorcycle dealers in General Santos City were all rated somewhat satisfied except for one, which was rated very satisfied. The highest mean rating of 4.60 indicated that the customers were very satisfied of the sales and marketing activities because the sales personnel/agents are polite and approachable. The findings of the study showed that personnel were generally polite and approachable. However, this does not mean that customers were totally satisfied with the services offered by dealers because there may be other indicators to be considered in establishing customers satisfaction in terms of sales and marketing. Other indicators that play a very significant contribution to total customers satisfaction include dealers' products prices, service offering, product quality and value of products in exchange for customers payment and loyalty to dealers. 
Table 5. Customer's level of satisfaction on sales and marketing.

\begin{tabular}{|c|c|c|}
\hline Indicators & Mean & Interpretation \\
\hline $\begin{array}{l}\text { 1) Sales personnel/agents are polite and } \\
\text { approachable. }\end{array}$ & 4.60 & Very Satisfied \\
\hline $\begin{array}{l}\text { 2) Sales personnel/agents are knowledgeable in selling } \\
\text { motorcycle products and parts. }\end{array}$ & 4.43 & Somewhat Satisfied \\
\hline $\begin{array}{l}\text { 3) Sales personnel/agents are honest in dealing with } \\
\text { the customers. }\end{array}$ & 4.45 & Somewhat Satisfied \\
\hline $\begin{array}{l}\text { 4) Sales personnel/agents attend to customers needs } \\
\text { promptly. }\end{array}$ & 4.33 & Somewhat Satisfied \\
\hline $\begin{array}{l}\text { 5) Dealer offers promotional freebies and other } \\
\text { promotional items provided by suppliers. }\end{array}$ & 3.95 & Somewhat Satisfied \\
\hline $\begin{array}{l}\text { 6) The motorcycle and spare parts products are priced } \\
\text { lower than the competitors. }\end{array}$ & 3.70 & Somewhat Satisfied \\
\hline $\begin{array}{l}\text { 7) The service rates are priced lower than the } \\
\text { competitors. }\end{array}$ & 3.63 & Somewhat Satisfied \\
\hline Overall & 4.15 & Somewhat Satisfied \\
\hline
\end{tabular}

Table 6. Customer's level of satisfaction on financing.

\begin{tabular}{|c|c|c|}
\hline Indicators & Mean & Interpretation \\
\hline 1) Dealer offers easy installment plan. & 4.33 & Somewhat Satisfied \\
\hline 2) Dealer offers low down payment. & 4.00 & Somewhat Satisfied \\
\hline 3) Dealer offers low interest rate on installment. & 3.73 & Somewhat Satisfied \\
\hline $\begin{array}{l}\text { 4) Dealer offers full payment discount, restructuring } \\
\text { and change term. }\end{array}$ & 4.25 & Somewhat Satisfied \\
\hline $\begin{array}{l}\text { 5) Dealer offers free registration and third-party } \\
\text { insurance. }\end{array}$ & 4.33 & Somewhat Satisfied \\
\hline $\begin{array}{l}\text { 6) Dealer has clear credit and collection policies } \\
\text { imposed to the applicants. }\end{array}$ & 4.53 & Very Satisfied \\
\hline $\begin{array}{l}\text { 7) Personnel strictly follow the company policies in } \\
\text { granting credit and collecting payments. }\end{array}$ & 4.35 & Somewhat Satisfied \\
\hline $\begin{array}{l}\text { 8) Dealer offers rebates and discounts to the products } \\
\text { and services. }\end{array}$ & 4.65 & Very Satisfied \\
\hline $\begin{array}{l}\text { 9) Dealer offers installment prices for motorcycle } \\
\text { products. }\end{array}$ & 4.45 & Somewhat Satisfied \\
\hline Overall & 4.29 & Somewhat Satisfied \\
\hline
\end{tabular}


Table 7. Customer's level of satisfaction on after sales services.

Indicators
1) Dealer provides suggestion box for the customer to
file complaints.
2) Dealer assigns customer service representative to
entertain inquiries and help find solution to complaints of customers.

3) Dealer follows a customer service protocol in serving customers.

4) Dealer provides temporary replacement for parts or service while repairing the motorcycle.

5) There are adequate personnel to attend to customers needs.

6) Personnel are accommodating in handling inquiries and complaints.

7) Personnel are recording the complaints and suggestions of customers.

8) Dealer offers free repair of motorcycle unit(s) and parts.

9) Dealer gives importance to the aspect of repair, maintenance and warranty.

10) Dealer's mechanic checks defective parts or service for warranty.

11) Dealer is prompt in replacing warrantable parts of motorcycle unit or parts.

12) Dealer's mechanic is well trained and expert in providing repair and maintenance.

13) Dealer's service shop is accessible.

14) Dealer's parking area is spacious to accommodate customers.

15) Dealer's shop is complete with tools and equipment.

16) Dealer's facilities are complete and offers comfortable ambience to stay while customers are waiting.

17) Repair and maintenance charges after warranty period is affordable.

$\begin{array}{cc}\text { Mean } & \text { Interpretation } \\ 2.90 & \begin{array}{c}\text { Neither Satisfied nor } \\ \text { Dissatisfied }\end{array}\end{array}$

3.78

Somewhat Satisfied

4.08 Somewhat Satisfied

2.98

Neither Satisfied nor Dissatisfied

Somewhat Satisfied

Somewhat Satisfied

Somewhat Satisfied

Very Satisfied

Neither Satisfied nor

Dissatisfied

4.35 Somewhat Satisfied

Very Satisfied

3.73 Somewhat Satisfied

Somewhat Satisfied

4.03 Somewhat Satisfied 
On the other hand, the lowest mean rating of 3.63 indicated that the customers were somewhat satisfied of the sales and marketing activities of motorcycle dealers because the service rates are priced lower than the competitors'. The result of the study revealed that customers were searching for dealers who offer low prices. The pricing scheme of dealers depends on the brand catered, degree of competition, location of dealers, market share, and income bracket of customers. The interview data presented that most of the customers were price sensitive and decides to buy or avail products and services from those who met customers price standard than competing dealers. Motorcycles are priced according to dealers' pricing strategies and most of them were vigilant in each other's price offerings in the market. Prices offered vary from dealers' goals which some dealers were concerned with profit; others were concerned with both the market share and profit. This may also imply that no matter how dealers adjust the prices the customers would always demand for low prices because of the customers buying behavior who were demanding for a price discounts and who were not aware of the effect of mark down to dealers' profit.

According to Balasan (2014) the pricing strategy that an organization uses depends on whether its operation is in a domestic or international market. The scheme varies on the type of market or target market the company is catering. Companies set a particular price for a purpose, it can be the company's want to meet the profit objective, maintain or improve market share or control entry of new entrants in the market offering of competing brand. It was further confirmed in the concept of Kotler \& Armstrong (2014) that customers perceptions of the product or service value set the ceiling for considerations in setting the price. If customers perceived that the product or service price is greater than its value, they will not buy the product or service. Product or service costs set the floor for prices. If the company prices both the product and service below its costs, the company's profit will suffer. The findings were affirmed by Manager A when he said that "Yes, there are competitors that really offer lower down payment than us, and we can do nothing about it if the customers will not patronize us". It was confirmed by Manager B when he revealed that "Maybe, it is in the customer service that we have to compete". Manager $\mathrm{H}$ confirmed that “Through competition about freebies ma'am, we offer free registration and TPL insurance. Others are adding for the insurance. In the price, we can also lower through the control of the owner". It was agreed by Manager D when he expounded that "Yes, we are an open market, usually we encounter it every day and prices will change. To us, since Motortrade operates business nationwide, when it comes to price, the interest rate is lower. But, if the company and dealer owned competitors, they have discretion to lower their prices, it is up to them. Our existing market price was approved to them". Manager $\mathrm{H}$ said that to combat price adjustments of competitors "If there are adjustments from competitors, upon verifying the prices of competitors that they had lower their prices we send the price to the head office through the owner to lower the price to compete with 
other dealers' prices". The statement was contradicted by Manager B when he confirmed that "We monitor competitors' prices monthly. So far, we did not observe any adjustment". He added that "The head office monitors the prices monthly. Once the prices are not competitive anymore, the head office will be the one to decide". It was contradicted in the statement of Manager A when he cited that "With regards to prices or sudden adjustment, we do not worry about it, because the higher-level management or the Operation Manager will check regarding prices".

Table 6 shows customers satisfaction level on financing activities of motorcycle dealers in General Santos City. The nine (9) indicators detailed in the table reflect satisfaction of customers to the policies and offers of motorcycle dealers in terms of financial plans that the customers may opt to choose.

Among these indicators, only two were rated very satisfied while the rest of the indicators were rated somewhat satisfied. The indicator with the highest rating of 4.65 indicated that the customers are very satisfied with the financing schemes because dealers offer rebates and discounts to the products and services. The result of the study showed that dealers' have rebates and discount rewards schemes intended for current accounts payer. This program is applicable only to those customers who pay on time or those customers who were not overdue. This is a good strategy to maintain collection efficiency however, although customers were aware of the rebates and discount reward system of dealers, it was not enjoyed by all customers and it was not a good motivator to those overdue customers because the customers would sacrifice not to avail the minimal amount of rebate which is two hundred pesos only. In fact, dealers were faced with problems and challenges on deposited units, meaning the collection strategies of dealers were not effective to customers.

According to Futrell (2014) discounts are given to buyers or customers for some reasons and based on the types of customers. The result of the study was confirmed in an interview with Manager A who said "To us, let us say, if due date falls on April 3, then we allow because of the 5 days allowance from due date provided, that previous payments were rebated. Let us say, 3 successive months were rebated on the 4 th month he was not able to avail the rebates, we allow the 5 days and we consider customers reasons". He added that "For prompt payment rebates, before, we gave them 100. Now, it was augmented to 200 rebates given to customers paying on or before due date". Moreover, Manager E expressed that "If it falls on Sunday or holiday, the next day, they can avail rebates". He added that "For now, base in Gensan, we have scheming on rebates of 500, 300, and 200". So, it is an advantage for us, because here in Gensan the rebate is 200 . This was contradicted by Manager B when he said that "It is not the rebates that he asks for, but it is the favor on discount of penalty charges and full waving of penalty".

Also shown in the table, the customers were very satisfied (4.53) of the same because the dealers have clear credit and collection policies imposed to the ap- 
plicants. Financing motorcycles units is the major business activity of motorcycle dealers. There are financing requirements imposed by dealers when granting credit to target buyers. It was confirmed in the theory of Briones (2005) that creation of efficient collection machinery is a necessary and legal undertaking. It has for its purpose the preservation of the creditors' resources so they can be deployed to the benefit of everyone. The result of the study was verified in the theory of Apolo (2003) specifying that the objective of collection management is to see to it that the unit or department tasked with the responsibility to collect is able to obtain payment promptly at a minimum cost and to maintain the goodwill of the customer.

The indicator with the lowest mean rating of 3.73 showed that the customers are somewhat satisfied of the financing schemes of motorcycle dealers because the dealers offer low interest rate on installment. According to Manager A " $\mathrm{Fi}$ nancing means that customers are paying monthly amortizations for the motorcycle for whatever terms he wishes to avail in the installment plan of 12,24 , or 36 months".

Overall, the customers are somewhat satisfied of the financing activities, with a rating of 4.29. The outcome of the findings revealed that one of the credit and collection procedures enjoyed by the customers are the rebates and discounts offered by dealers and the credit and collection policies. However, this may not be enough for the customers to be satisfied with the services of dealers in terms of financing, because customers were searching for dealers who can provide other more alternative financing schemes such as lower down payment and lower interest rates. Business News (2015) stated that Motorcycle and Scooter India, a subsidiary of Honda Motor Company has collaborated with Shriram Automall which offered financing of pre-owned bikes and scooters as strategy to their price offerings. The outcome of the study was validated in the study of Anantadjaya et al. (2011) entitled, "Ratio Analysis on Entrepreneurial Service Quality: A Case Study in a Motorcycle Dealership in Java". The study found out that in order to improve the financial conditions of the dealer, the owner had set strategies to increase sales via additional flexibilities in monthly installments and total down payment. According to Walker Jr. \& Mullins (2014) customers develop perceptions by comparing the prices being charged by a firm and its competitors to the benefits or value they think they can derive from purchasing the product or service.

Shown in Table 7 are the indicators and their corresponding mean ratings on customers satisfaction on after sales activities of motorcycle dealers of General Santos City. Seventeen (17) indicators were formulated to reflect customers satisfaction on this area of motorcycle dealership.

Among the 17 indicators, only two (2) were rated very satisfied by the customer-respondents. These two items indicated that the customers were very satisfied because the dealer's mechanics check defective parts or service for warranty and the dealer's service shop is accessible. The findings of the study revealed that mechanics are checking the veracity of defective parts of motorcycle 
unit complaint by customers. Although, mechanics attended the needs of customers specifically, on defective parts yet, customers were not fully satisfied because customers want immediate action in replacing damaged parts identified by mechanics, some of which may not be available immediately.

The result of the study was affirmed by Manager A who stated that "There were problems regarding the warranty of spare parts that arrived late because it came from the central office, in NCR through Manila. As practiced, suppliers like Honda, Kawasaki, Yamaha, Suzuki and Skygo imposed policies and processes to be followed in claiming and ordering of spare parts that often times causes delays to those spare parts problems that needs immediate replacement for the motorcycle unit to be functional again". According to Manager E when he expounded that "If we order spare parts, the longest time is one week, except for the latest model, because there are no available spare parts". It was contradicted in the study of Ravindra \& Sorsa (2015) entitled, "a Study on Customer Satisfaction towards BAJAJ Motorbikes in Hawassa, Euthopia, Africa", it was found out that eighty percent $(80 \%)$ of the respondents express their satisfaction with the availability of spare parts.

It is interesting to note that there are three (3) items that were rated neither satisfied nor dissatisfied. These items indicate that the customers are sometimes satisfied but sometimes also dissatisfied of the dealers' after sales services because 1) the dealers provide suggestion box for the customer to file complaints, 2) the dealers provide temporary replacement for parts or service while repairing the motorcycle and 3) the dealers are prompt in replacing warrantable parts of motorcycle unit or parts, with mean ratings of $2.90,2.98$, and 3.38, respectively. The rest of the indicators, which comprise the majority, of satisfaction were rated somewhat satisfied, ranging from 3.73 to 4.35 mean ratings.

On the item, the dealers provide suggestion box for the customers to file complaints. The result of the study presented that some customers were looking for suggestion boxes for them to discretely give feedback to the management of the services experienced especially, the unpleasant or bad service provided by personnel. Suggestion box is one of the ways for dealers to gather information and know the comments and suggestions of customers on a particular product or service. Customers want the motorcycle dealers to pay attention to customers complaints through provision of suggestion boxes because there were customers who cannot personally bring up their observation and experiences of a quality service or disservice. According to Bateson \& Hoffman (2011) Indirect measures of satisfaction are generally obtained via customer satisfaction surveys that include tracking of customer complaints through feedback using suggestion and complaint boxes. The result of the study was verified by Manager E when he explained that "Usually ma'am, we have a complaint book, all complaints were log depending on the complaints like for example the registration of motorcycle. We have a complaint book".

In addition, the findings of the study revealed that customers were aware of 
the business practices of dealers. In order to inform dealers of the products and service flaws, customers want to communicate by means of expressing complaints and feedback through suggestion boxes, it means that customers want to correct disservice to avail an excellent service dealer could provide to the customers. It also showed that managers were not knowledgeable enough on how to gather information to improve services rendered by personnel. Customers feedback is important in recovering the service flaws of dealers to avoid spreading of rumors that customers do as reaction to the bad experiences from dealers and to evade legal risk in the future which could be avoided if managers would give focus on how the products and services can be improved. It is easier and inexpensive to keep an existing customer than to win a new customer. Poor complaints handling drives customers away, and they will not come back to avail the service again. Even if customers do not complain directly to the dealers, the latter will loss the customers after having their first complaints. The findings of the study were confirmed in the theory of Bell \& Luddington (2006) who expounded that in smaller companies, there is often no process in place for dealing with complaints. This tends to increase the likelihood that it will be managed ineffectively. Another theory that affirmed the result of the study was the concept of Dunn \& Dahl (2012) who had explicated that influence of customer complaint on consumer reactions to a product was examined. Consumers have been found to feel better about product failure after complaining about the problem.

On the item, the dealers provide temporary replacement for parts while repairing the motorcycle. The result of the survey indicated that customers want a speedy remedy for the replacement of defective parts while the motorcycle units are repaired. Customers do not want to wait longer for the replacement of defective spare parts and delays in delivery of parts would mean a disservice to the customers. Spare parts are vital components of a motorcycle without which, the engine would not be functional and postponement on customers end would also mean losses for some of the motorcycles are used as a personal service or as public transportation like tricycle or as delivery vehicle for small scale businesses. The findings of the study showed a clear manifestation of the dealers' lack of ability to strategize on how to better serve the customers especially on ways to provide alternative solutions to customers like replacing defective parts temporarily or for the meantime while the dealer is claiming the warranty parts. It also showed that perhaps the managers' are incompetent in dealing with problems that needs immediate solution like replacing damaged parts that may continue to arise if not given proper attention because customers want a speedy solution from dealers. The result also revealed that dealers' and suppliers' policies in replacing damaged spare parts or warrantable parts were not properly devised and fully understood by customers. In fact, there was no comprehensive customer satisfaction plan designed for customers because dealers' do not consider the replacement parts in lieu of warranty as priority to make customers totally satisfied. This may also imply that dealers' practices in providing services in the as- 
pect of after sales service needs to be redesigned because the problem had continuously occurred. The result of the study was affirmed by Manager D when he mentioned that "Ah, that's it, that is why, we do not stock if you can see we do not have spare parts, order and the required are what we are doing here because it is really a problem in the process log especially, the ordering. SAP is more on computerization, the branch will order through the head office prior to forwarding to the supplier. The process is long so, we advised them to buy from the accredited spare parts". According to Castleberry \& Tanner Jr. (2014) there are two types of warranty, the express and implied warranty. An expressed warranty is an oral or written statement by the seller. An implied warranty is not actually stated but is still an obligation defined by the law like products are used in the manner stated by seller.

On the item, the dealers are prompt in replacing warrantable parts of motorcycle unit or parts. The result of the survey implied that the dealers are not quick in replacing warrantable parts because the suppliers were not delivering the warrantable parts on time. Dealers are dependent on the replacement of warrantable items from their respective suppliers. In fact, delivery of spare parts under warranty usually takes one week to one month from the central office in Manila. The result of the study presented that managers were not coordinating with the suppliers in the delays of warrantable parts for replacement. This may imply that motorcycle dealers lack concerns for customers over delayed replacement of warrantable parts. Both parties should work hand in hand in providing quality services to the customers especially, that some of the motorcycles are bought through installment basis and the units are used for public transport, delivery, collection and other business transactions that would hamper business operations of the customers and would result to lost opportunity and business losses that directly affect the business operations of dealers.

Manager $\mathrm{C}$ conformed the result of the study when she stressed that "The warrantable parts if not available, repair depends on the availability of spare parts so, it will be repaired late. The interview outcome was affirmed by Manager B who said that "For the warranty, there are suppliers that are fast in responding to warranty, there are suppliers who are slow in the approval in the head office in Manila". It was further confirmed by Manager A who said that "There are problems that it really arrived late because it came from the central office through Manila. It is where it came from regarding warranty parts".

The next table shows the summary of customers satisfaction level on services of motorcycle dealers in General Santos City.

As shown in Table 8, the customer-respondents were all somewhat satisfied of the services the dealers offer or provide to them, as summed in the three areas of satisfaction. But among the three areas, it is in financing that they are more satisfied and it is in after sales services that they are less satisfied than the rest. The results of the study were corroborated in the study of Fazlzadeh, Bagherzadeh, \& Mohamadi (2011) entitled, "How After sales Service Quality Dimension Affect 
Customer Satisfaction", found out that after sales service quality affect satisfaction, which in turn affects the customers intentions in buying any product. It also substantiated that after sales service influenced the perceived value by the customer and as a result, the quality of the relationships between actual buyers and sellers. It became obvious that the importance of after sales services for customer satisfaction could be essential; and the result shows that customer satisfaction was measurable.

\subsection{Relationship between the Motorcycle Dealers' Business Practices and Customers Level of Satisfaction}

In Table 9, the matrix of correlation coefficients is presented to show the significance of relationship between dealers' business practices and the customers level of satisfaction on the services and offers provided by the motorcycle dealers in General Santos City.

As shown in Table 9, the three areas of dealers' business practices, namely: management, sales and marketing, and financing were each tested correlationally on each of the three areas of customers satisfaction, namely: sales and marketing, financing, and after sales services. Also tested using Pearson $r$ correlation are the overall business practices and the overall customers satisfaction. As a result, a $4 \times 4$ correlation matrix was designed. These coefficients were computed using SPSS 20.

Table 8. Summary of customers level of satisfaction on services of motorcycle dealers in general Santos city.

\begin{tabular}{ccc}
\hline Area & Mean & Interpretation \\
\hline Sales and Marketing & 4.15 & Somewhat Satisfied \\
Financing & 4.29 & Somewhat Satisfied \\
After Sales Services & 3.91 & Somewhat Satisfied \\
Overall & 4.07 & Somewhat Satisfied \\
\hline
\end{tabular}

Table 9. Pearson $\mathrm{r}$ correlation matrix between dealers' business practices and level of customers service satisfaction.

\begin{tabular}{|c|c|c|c|c|c|}
\hline \multirow{2}{*}{\multicolumn{2}{|c|}{ Pearson $\mathbf{r}$}} & \multicolumn{4}{|c|}{ Customers Service Satisfaction } \\
\hline & & Sales and Marketing & Financing & After Sales Services & Overall \\
\hline \multirow{4}{*}{$\begin{array}{c}\text { Dealers' Business } \\
\text { Practices }\end{array}$} & Management & -0.032 & 0.068 & -0.466 & -0.381 \\
\hline & Sales and Marketing & 0.467 & 0.208 & 0.601 & $0.736^{*}$ \\
\hline & Financing & -0.068 & 0.528 & -0.108 & 0.155 \\
\hline & Overall & $0.761^{*}$ & 0.129 & $0.875^{* *}$ & 0.435 \\
\hline
\end{tabular}

${ }^{\star}$ Correlation is significant at the 0.05 level (2-tailed); ${ }^{* *}$ Correlation is significant at the 0.01 level (2-tailed). 
Among the sixteen (16) correlation coefficients, only three (3) indicated significant relationships, two (2) of which were significant at 0.05 level of significance and one (1) of which was significant at 0.01 level. It is established that the overall business practices (three areas of business practices combined) are significantly correlated with the customers level of satisfaction with sales and marketing the dealers do. On the other hand, it is established that the sales and marketing practices of dealers are significantly correlated to the overall customers level of satisfaction (three areas of satisfaction combined). It is interesting to note that the overall business practices (three areas of business practices combined) are very significantly correlated with the customers level of satisfaction on after sales services provided or offered by the motorcycle dealers to their customers. In other words, these significant coefficients of correlation indicate that in these areas, the dealers' business practices have an effect on the customers level of satisfaction.

Apart from the three significant correlation coefficients, also shown in Table 8 are other coefficients of correlation using Pearson $r$, which were tested to be non-significant. Five (5) of these non-significant coefficients are negative, such as those between dealers' management practices and customers satisfaction on sales and marketing $(-0.032)$ and between dealers' management practices and customers satisfaction on after sales services $(-0.466)$.

The correlation coefficient between the dealers' sales and marketing practices and the customers satisfaction on after sales services is high (0.601), but was found to be not significant. In other words, the dealers' sales and marketing practices may not be enough for the customers to be satisfied in the area of after sales services. Hence, the dealers need to put extra effort on their sales and marketing strategies to give more satisfaction to their customers.

\section{Conclusion}

Based on the results and findings of the study the following conclusions were drawn:

1) Dealers' have excellent inventory and distribution management system. Although, the motorcycle industry was very proficient in the aspect of management yet, there are areas that need to be developed like provision of customer service trainings to personnel in customers complaints handling and human relations aside from the technical trainings provided to cater complaints directly received from customers.

2) The industry's sales and marketing campaign contribute to the attainment of desired financial goal. Dealers have no consistent and comprehensive marketing campaign efforts due to reliance on subsidies of suppliers in conducting marketing activities.

3) Motorcycle industry's core competency in the aspect of finance is the clear credit and collection policies and seminars provided to improve skills in performing duties and responsibilities. In spite of the best practices presented, 
training provided to credit and collection personnel must be evaluated due to performance deviations. There were problems and challenges faced by dealers like customers who were looking for more alternative financing schemes in terms of lower down payment, lower interest rates and dishonesty due to bribery.

4) The motorcycle industry is very dynamic. For dealers to stay competitive and to achieve total customers satisfaction, the industry must provide alternative solution to answer immefdiate need of customers in the after-sales service concerns. Profitability of motorcycle dealers is anchored on core competencies of dealers and the level of customers satisfaction. Thus, managers' performances must also be reviewed for management's intervention and corrective actions.

\section{Recommendations}

In the light of the findings and conclusions the following recommendations were formulated:

1) Training needs assessment must be conducted by dealers to evaluate specific training suited to each individual necessary to improve skills especially, those who are directly providing services to the customers. A 360 degrees performance appraisal must also be conducted to determine the individual attitudes and behaviors of personnel to correct service flaws most especially, those identified by the customers. The industry must also look into consideration for the qualifications of managers and assess the trainings provided in overseeing the branch operations.

2) Dealers must conduct a competitive benchmarking from dealers in other regions to launch a consistent comprehensive marketing campaign using effective marketing tools like intermediaries and tri-media in promoting the products and services. Dealers must also offer an attractive extrinsic reward not only to sales personnel but rewards applicable to all personnel for them to strive to work efficiently and effectively to generate more sales and improve profitability.

3) Dealers must conduct a process benchmarking from dealers in other regions to reengineer service strategy to further improve service delivery especially in the areas of after sales services. There must be a supplier-dealer support system in place to immediately address warranty concerns.

4) Dealers must also review the organizational culture and current practices on management, sales and marketing, financing, and after sales services aspects that are not effective anymore. Dealers should not focus on core competencies, instead dealers must focus on the weaker areas that needs improvement and must engage into strategic planning to devise an effective comprehensive plan to efficiently and effectively serve customers needs.

5) This study is quantitative research data were gathered based on respondent's personal perception. The data gathered might not be the representation of the experiences of the whole motorcycle dealers and customers in General Santos City considering every motorcycle dealer is unique, and business practices 
might not be necessarily their concerns. Thus, similar studies may be done in the future in a larger scope and using other methodologies to assure reliability, validity and more in-depth scrutiny ensuring better business practices and high level of customer satisfaction. Further studies may be done in the future like credit and collection practices, and credit risk management practices which are also important for motorcycle dealers' businesses.

\section{Acknowledgements}

The researchers commend the participation of the motorcycle dealers and their customers in the conduct of this study. Moreover, the researchers acknowledge the support provided by the administration of the Ramon Magsaysay Memorial Colleges (RMMC) in making this study viable.

\section{Conflicts of Interest}

The authors declare no conflicts of interest regarding the publication of this paper.

\section{References}

Adusei, C., \& Tweneboah-Koduah, I. (2019). After-Sales Service and Customer Satisfaction in the Automobile Industry in an Emerging Economy. Open Access Library Journal, 6, 1-21. https://doi.org/10.4236/oalib.1105167

Amojelar, D. (2012). DTI Probing Complaints vs. Motorcycle, Car Dealers Who Insist on Financing. InterAksyom.com. http://www.interaksyon.com/business/35845/dti-probing-complaints-vs--motorcycle-c ar-dealers-who-insist-on-financing

Anantadjaya, S. P. D., Pratama, C., Nawangwulan, I. M., Sibarani, M., \& Riwoe, J. C. (2011). Ratio Analysis on Entrepreneurial Service Quality: A Case Study in a Motorcycle Dealership in East Java. The 3rd Indonesia International Conference on Innovation, Entrepreneurship \& Small Business (IICIES 2011), Center for Innovation, Entrepreneurship, and Leadership (CIEL), School of Business \& Management, Institut Teknologi Bandung. https://papers.ssrn.com/sol3/papers.cfm?abstract_id=1912210

Apolo, J. T. (2003). Credit and Collection Management in the Philippine Setting (2nd ed.). Mandaluyong City, Philippines: National Bookstore.

Balasan, M. N. (2014). Marketing Basics: A Modular Approach. Manila: Philippines: Rex Bookstore.

Bateson, J. E. G., \& Hoffman, K. D. (2011). Services Marketing. Boston, MA: Cengage Learning.

Bell, S. J., \& Luddington, J. A. (2006). Coping with Customer Complaints. Journal of Service Research, 8, 221-233. https://doi.org/10.1177/1094670505283785

Bloor, M., \& Wood, F. (2006). Purposive Sampling. In M. Bloor, \& F. Wood, Keywords in Qualitative Methods (p. 143). Thousand Oaks, CA: SAGE Publications Ltd. https://doi.org/10.4135/9781849209403.n73

Bowersox, D. J., Closs, D. J., Cooper, M. B., \& Bowersox, J. C. (2014). Supply Chain Management Logistics Management (4th ed.). New York: McGraw-Hill Education.

Briones, J. G. (2005). Credit and Collection Management Made Easy for Filipino College 
Students. Mandaluyong, Philippines: National Book Store.

Business News (2015). Honda Partners Shriram Automall.

https://www.overdrive.in/news-cars-auto/honda-teams-up-with-shriram-automall-tooffer-pre-owned-two-wheelers/

Calmorin, L. P., \& Calmorin, M. A. (2012). Research Method and Thesis Writing (2nd ed.). Manila, Philippines: Rex Bookstore, Inc.

Carmudi, P. H. (2018). Philippine Motorcycle Industry Sees Growing Need for Motorcycles. https://www.carmudi.com.ph/journal/philippine-motorcycle-industry-sees-growing-ne ed-motorcycles/

Castleberry, S. B., \& Tanner Jr., J. F. (2014). Selling: Building Partnerships (9th ed.). New York: McGraw-Hill Education.

Dubrin, A. J. (2013). Fundamentals of Management (Philippine ed.). Boston, MA: Cengage Learning.

Dunn, L., \& Dahl, D. W. (2012). Self-Threat and Product Failure: How Internal Attributions of Blame Affect Consumer Complaining Behavior. Journal of Marketing Research, 49, 670-681. https://doi.org/10.1509/jmr.11.0169

eportal.gensantos.gov.ph (2020). About General Santos City—Economy. https://eportal.gensantos.gov.ph/about-general-santos/

Evans, J. R., \& Lindsay, W. M. (2013). Managing for Quality and Performance Excellence (9th ed.). Boston, MA: Cengage Learning.

F+L Daily (2017). Philippine Motorcycle Market Continues Gains in 2017. https://www.fuelsandlubes.com/philippine-motorcycle-market-continues-gains-in-2017/

Fazlzadeh, A., Bagherzadeh, F., \& Mohamadi, P. (2011). How After-Sales Service Quality Dimensions Affect Customer Satisfaction. African Journal of Business Management, 5, 7658-7664. http://www.academicjournals.org/AJBM https://doi.org/10.5897/AJBM11.351

Futrell, C. M. (2014). Fundamentals of Selling: Customer for Life through Service (13th ed.). New York: McGraw-Hill Education.

Garcia, N. P., \& Juevesa, R. D. (2020). Workplace Spirituality in State Universities and Colleges: Its Relation to the Work Well-Being and Job Satisfaction of Faculty Members. International Journal of Engineering and Management Research, 10, 52-67.

https://ssrn.com/abstract=3718970

https://doi.org/10.31033/ijemr.10.5.12

Griffin, R. W., \& Morehead, G. (2014). Organizational Behavior (Philippine ed.). Boston, MA: Cengage Learning.

Guillen, M. D. V., \& Ishida, H. (2004). Motorcycle-Propelled Public Transport and Local Policy Development: The Case of "Tricycles" and "Habal-Habal" in Davao City, Philippines. IA TSS Research, 28, 56-66. https://doi.org/10.1016/S0386-1112(14)60092-3

Hanlon, M. (2012). New Research Indicates Motorcycle Commuting Reduces Traffic Congestion and Emissions.

https://newatlas.com/motorcycles-reduce-congestion/21420/

Heizer, J., \& Render, B. (2014). Operations Management Sustainability and Supply Chain Management (11th ed.). New York: Pearson Education.

Kotler, P., \& Armstrong, G. (2014). Principles of Marketing (15th ed.). New York: Pearson Publishing.

Kurtz, D. L. (2013). Principles of Contemporary Marketing (Philippine ed.). Boston, MA: Cengage Publishing. 
Laurel, D. (2017). We Ask the LTO about the Ongoing OR/CR Issue, Top Gear Philippines.

https://www.topgear.com.ph/news/motoring-news/lto-or-cr-issue-a00013-20170217

Liu, C. (2001). An Assessment of Banking Operation Strategies of Private Banking Institutions in the Philippines. Asia Pacific Journal of Marketing and Logistics, 13, 57-71. http://www.emeraldinsight.com/doi/abs/10.1108/13555850110764711 https://doi.org/10.1108/13555850110764711

Maddox, J. (2016). Top 4 Complaints about Motorcycle Dealerships. MC Garage. https://www.motorcyclistonline.com/top-4-complaints-about-motorcycle-dealerships/

Magkilat, B. (2014). Motorcycle Roadmap. Manila Bulletin. http://www.mb.com.ph/crs-canwait-but-not-motorcycles-roadmap

Medina, R. (2012). Principles of Marketing (Revised ed.). Manila, Philippines: Rex Bookstore, Inc.

Populationstat.com (n.d.). General Santos City Population as of 2017. https://populationstat.com/philippines/general-santos-city

Ravindra, K., \& Sorsa, G. (2015). A Study on Customer Satisfaction towards Bajaj Motorbikes in Hawassa City, Hawassa-Ethiopia, Africa. International Journal of Logistics and Supply Chain Management Perspectives, 4, 1451-1456. https://pezzottaitejournals.net/pezzottaite/2015_IJLSCMP_PAGE_OF_CONTENTS_V 4N1_JANUARY_MARCH.php

Reinsalu, A. (2018). Small and Light Might Be the Solution for Urban Traffic. https://medium.com/the-stigo-blog/small-and-light-might-be-the-solution-for-urban-t raffic-3d233b3a83ba

Roces, I. S. (2018). Philippine Motorcycle Sales up 21\% in 2018. Motocycle News. https://www.motopinas.com/motorcycle-news/philippine-motorcycle-sales-up-21-in-2 018.html

Sino Cruz, I. R. (2019). Car Dealer Gets Notice to Explain from LTO-7 over Complaint of Client on Delayed Release of Registration. Cebu Daily News. https://cebudailynews.inquirer.net/262081/car-dealer-gets-notice-to-explain-from-lto7-over-complaint-of-client-on-delayed-release-of-registration\#ixzz6jUGvBFuO

Tamehiro, T. (2019). Yamaha Fights for Pole Position in Philippine Motorcycle Market. https://asia.nikkei.com/Business/Business-trends/Yamaha-fights-for-pole-position-inPhilippine-motorcycle-market

Walker Jr., O. C., \& Mullins, J. W. (2014). Marketing Strategy: A Decision Focused Approach (8th ed.). New York: McGraw-Hill Education.

Young, F. C., \& Pagoso, C. M. (2012). Principles of Marketing. Manila, Philippines: Rex Bookstore, Inc. 